\title{
PENGEMBANGAN MODEL LATIHAN KEBUGARAN JASMANI BERBASIS PERMAINAN TRADISIONAL SEBAGAI AKTIVITAS BELAJAR SISWA DALAM PEMBELAJARAN PJOK
}

\author{
Robertus Lili Bile', Yohanes B.O. Tapo², Avelina K. Desi ${ }^{3}$ \\ 1,2,3 Prodi Pendidikan Jasmani, Kesehatan dan Rekreasi, \\ STKIP Citra Bakti Ngada, Indonesia \\ e-mail: robertuslilibile16@gmail.com,yohanesbayoolatapo@gmail.com, \\ avelinakdesi@gmail.com

\begin{abstract}
Abstrak
Inovasi pembelajaran penjas yang efektif dan menyenangkan perlu dilakukan secara berkala agar menambah alternatif model pembelajaran yang dapat memacu peningkatan motivasi belajar siswa. Penelitian ini merupakan jenis penelitian dan pengembangan yang bertujuan untuk: (1) mengembangkan model latihan kebugaran jasmani berbasis permainan tradisional, (2) menguji kelayakan penggunaan produk pengembangan. Desain penelitian meliputi (1) penelitian produk yang telah ada, (2) perencanaan pengembangan produk, (3) Pengujian internal desain tahap I, (4) revisi produk I, (5) pengujian internal desain tahap II, (6) revisi produk II, (7) produk akhir. Tempat dan subyek penelitian yaitu siswa SMP Citra Bakti berjumlah 9 orang. Data penelitian dikumpulkan menggunakan angket skala nilai. Analisis data menggunakan teknik analisis deskriptif kualitatif dan kuantitatif. Hasil penelitian adalah (1) model latihan kebugaran jasmani berbasis permainan tradisional sebagai aktivitas belajar siswa yang diberi nama Model Latihan Play4Fit. (2) model latihan kebugaran jasmani berbasis permainan tradisional (Play4Fit) memenuhi kategori "sesuai" (layak) digunakan sebagai bentuk aktivitas belajar siswa pada materi latihan kebugaran jasmani dalam pembelajaran penjas.
\end{abstract}

Kata kunci: model latihan, kebugaran jasmani, permainan tradisional, aktivitas belajar, pendidikan jasmani

\begin{abstract}
Physical education learning innovations that are effective and fun need to be done regularly in order to add alternative learning models that can spur an increase in student motivation. This research is a type of research and development that aims to: (1) developing a model of physical fitness training based on traditional games, (2) testing the feasibility of using the development product. Research design includes (1) research on existing products, (2) product development planning, (3) Internal testing of design phase I, (4) product revision I, (5) internal testing of design phase II, (6) product revision II, (7) the final product. Research subjects are SMP Citra Bakti students. The research data were collected using a value scale questionnaire. Data analysis used qualitative and quantitative descriptive analysis techniques. The results of the study are (1) traditional game-based physical fitness training models as student learning activities namely Play4Fit. (2) traditional game-based fitness training models (Play4Fit) meet the "fit" category (feasible) to use as a form of student learning activities on physical fitness training material in physical education learning.
\end{abstract}

Keywords: training model, physical fitness, traditional game, learning activity, physical education.

\section{PENDAHULUAN}

Pendidikan Jasmani Olahraga dan Kesehatan (PJOK) dalam pembelajaran pada hakekatnya merupakan bagian integral dari sistem pendidikan secara umum yang bertujuan untuk mengembangkan aspek kesehatan, kebugaran jasmani, keterampilan fisik, keterampilan berfikir kritis, kematangan emosional, kecakapan sosial, penalaran dan tindakan moral melalui aktivitas jasmani dan olahraga. PJOK sejatinya bertujuan 
untuk membantu anak agar tumbuh dan berkembang secara wajar sesuai dengan tujuan pendidikan nasional, yaitu menjadi manusia sebagaimana semestinya. PJOK merupakan proses pembelajaran jasmani melalui kegiatan fisik yang dilakukan secara sadar dan sistematis untuk meningkatkan kebugaran tubuh, serta peningkatan dan perkembangan aspek jasmani, psikomotor, kognitif, dan afektif setiap peserta didik (Tapo, 2019).

Dalam konteks pemeliharaan dan peningkatan kebugaran jasmani, PJOK memainkan peranan yang cukup penting. Hal ini mengingat karakteristik pelaksanaan PJOK yang selalu melibatkan aspek gerak fisik dalam hampir tiap materinya yang memungkinkan anak untuk selalu aktif bergerak. Secara tidak langsung, melalui berbagai aktivitas gerak dalam pembelajaran PJOK, tingkat kesehatan fisik siswa akan menjadi baik dan dapat meningkat kearah yang semakin optimal. Aspek kesehatan fisik merupakan aspek utama dalam pemenuhan kesehatan total. Hal ini karena kesehatan fisik merupakan komponen penunjang aspek kesehatan lainnya yakni aspek kesehatan mental, kesehatan sosial dan kesehatan spiritual (Tapo \& Bile, 2020). Pada prinsipnya, kebugaran jasmani mencakup dua hal yakni kebugaran umum dan kebugaran spesifik. Kebugaran umum berkaitan erat dengan tingkat kesehatan dan kesejahteraan sedangkan kebugaran spesifik berkaitan dengan kemampuan individu dalam menyelesaikan tugas gerak baik dalam aktivitas pekerjaan maupun olahraga (Powel, 2011). Kebugaran jasmani merupakan kemampuan seseorang untuk menyelesaikan pekerjaan setiap hari dengan mudah, tanpa menimbulkan rasa lelah yang berarti, dan masih memiliki cadangan tenaga untuk merasakan waktu senggangnya dan untuk keperluan mendadak (Suharjana, 2008). Secara sederhana, kebugaran jasmani dapat dipahami sebagai refleksi kadar kemampuan seorang individu dalam melakukan berbagai tugas gerak secara maksimal dan efisien dalam rangka pemenuhan kebutuhan hidup tanpa mengalami kelelahan berlebihan serta terhindar dari berbagai resiko penyakit (Bile \& Suharharjana, 2019). Kondisi sehat dan bugarnya seseorang dipengaruhi oleh banyak hal. Latihan fisik dan olahraga yang tepat, teratur serta berkelanjutan merupakan komponen yang turut mempengaruhi peningkatan kondisi kebugaran jasmani seseorang (Bile \& Suharjana, 2019).

Aktivitas latihan fisik atau olahraga dapat dilakukan dengan cara memilih jenis latihan yang disenangi dan sesuai dengan tingkat kemampuan fisik masing-masing. Pengembangan aspek gerak fisik yang adekuat untuk tujuan pemeliharaan kondisi kebugaran jasmani siswa, perlu dilakukan secara teratur dan berkesinambungan sedini mungkin sehingga dapat menjadi sebuah kebiasaan yang positif bagi siswa. Sehubungan dengan hal ini, sebuah hasil riset yang dilakukan oleh Monyeki et al (2012) merekomendasikan agar program pemeliharaan kebugaran jasmani melalui intervensi latihan fisik ataupun olahraga dapat dilakukan sejak dini dengan memperhatikan faktorfaktor yang meliputi beban dan intensitas latihan yang sesuai dengan tingkat usia. Sehubungan dengan konsep kebugaran tersebut, maka yang perlu diperhatikan dalam usaha pemeliharaan kebugaraan jasmani adalah beberapa komponen yang meliputi daya tahan kardiorespirasi, daya tahan dan kekuatan otot, kelentukan serta komposisi tubuh (Irianto, 2017).

Berdasarkan hasil observasi pada proses pembelajaran PJOK terutama pada pembelajaran materi latihan kebugaran, aktivitas latihan kurang terlaksana dengan efektif. Jenis latihan yang monoton dan kurang sesuai dengan karakteristik siswa usia SMP masih menjadi faktor penyebab kurangnya antusias siswa dalam mengikuti skema pembelajaran PJOK yang diberikan. Pada umumnya siswa SMP lebih tertarik dengan aktivitas permainan yang menyenangkan namun tetap memacu kinerja fisik secara maksimal. Pada fase ini, perlu ada inovasi yang lebih disesuaikan dengan tingkat perkembangan fisik dan emosional siswa. Latihan fisik yang diberikan hendaknya didesain lebih menarik dan bervariasi dengan tuntutan kinerja fisik yang sesuai dengan usia SMP. Dalam konteks ini, permainan tradisional menjadi salah satu alternatif 
kearifan lokal yang dapat dimanfaatkan untuk tujuan pemeliharaan kebugaran fisik siswa.

Olahraga tradisional merupakan warisan kebudayaan nenek moyang bangsa Indonesia. Olahraga tradisional harus memenuhi dua unsur yaitu berupa "olahraga" atau olah tubuh "tradisional" atau kuno yang berkembang dari beberapa generasi yang memiliki kebiasan maupun dalam arti sesuatu yang terkait dengan kebiasaan budaya dari suatau bangsa secara menyeluruh (Ardiwinata, 2006). Dalam permainan tradisional tidak hanya sekedar bermain tetapi mengandung komponen kebugaran jasmani seperti dalam permainan lompat tali, permainan engklek, permainan balap karung. Dalam permainan tradisional tersebut memiliki unsur diantaranya adalah kekuatan otot, kelenturan otot, kecepatan gerak dan keseimbangan, serta daya tahan jantung paru. Nilai kebudayaan yang terkandung didalam bentuk olahraga tradisional adalah penghargaan pada usaha yang keras untuk mencapai prestasi olahraga yang ungggul, penghargaan pada prestasi orang lain, ikatan kelompok religiusitas dan lain- lain. Permainan tradisional seperti contoh permainan yang sudah disebutkan di atas merupakan sebagai penopang atau alat pendorong bagi siswa dalam meningkatkan keterampilan latihan fisiknya atau mengembangkan motorik kasar dan motorik halus dari seseorang dan merupakan salah satu strategi yang baik bagi guru terutama dalam pembelajaran penjas untuk mencapai tujuan pembelajaran. Permainan tradisional memiliki peran penting terhadap perkembangan keterampilan motorik kasar dan motorik halus bagi siswa seperti berjalan, berlari, melempar dan melompat. Permainan tradisional juga memiliki peran dan manfaat yang sangat penting bagi komponen kebugaran jasmani seperti kelenturan, kelincahan, keseimbangan, kecepatan, dan daya tahan jantung paru. Hal ini bisa dibuktikan dengan adanya gerakan- gerakan dalam permainan tradisional yang mengarah pada keterampilan motorik kasar dan gerakan yang mempunyai pengaruh terhadap kebugaran tubuh. Dengan demikian dapat disimpulkan bahwa latihan kebugaran jasmani berbasis permainan tradisional dapat digunakan sebagai alternatif bentuk latihan dan aktivitas belajar siswa dalam pelaksanaan pembelajaran PJOK terkusus pada meteri latihan kebugaran jasmani untuk mengembangkan aspek kebugaran fisik siswa (Tapo \& Bile, 2020).

Berdasarkan uraian permasalahan di atas, maka perlu dilakukan penelitian dengan judul "Pengembangan model latihan kebugaran jasmani berbasis permainan tradisional sebagai aktivitas belajar siswa SMP dalam pembelajaran PJOK“. Tujuan penelitian ini adalah 1) mengembangkan model latihan kebugaran jasmani berbasis permainan tradisional. 2) menguji kelayakan penggunaan produk model latihan kebugaran jasmani berbasis permainan tradisional. Produk yang dikembangkan dalam penelitian ini adalah model latihan kebugaran jasmani berbasis permainan tradisional sebagai aktivitas belajar siswa dalam pembelajaran PJOK. Model latihan ini didesain secara baik, teratur dan sistematis sehingga memudahkan siswa dalam mempraktekkanya. Dengan menggunakan model latihan kebugaran jasmani berbasis permainan tradisional ini sebagai aktivitas belajar siswa dalam pembelajaran PJOK diharapkan dapat memberikan manfaat yang baik bagi pemeliharaan tingkat kebugaran jasmani.

Latihan kebugaran jasmani berbasis permainan tradisional yang dikembangkan menitikberatkan pada desain aktivitas gerak fisik siswa melalui variasi permainan tradisional yang diarahkan sebagai aktivitas belajar siswa dalam pembelajaran PJOK materi kebugaran jasmani. Karakteristik permainan tradisional yang sederhana, menarik dan bersifat kompetitif diharapkan akan dapat memacu semangat siswa dalam mengikuti alur pembelajaran PJOK yang lebih optimal. Desain aktivitas gerak dibuat sedemikian rupa sehingga mampu merangsang siswa untuk terus bergerak aktif selama pembelajaran PJOK. Dengan adanya model latihan kebugaran jasmani ini diharapkan dapat membantu dan mempermudah peserta didik dalam memahami materi kebugaran 
ISSN 2356-3397 (Print) | ISSN 2597-4505 (Online)

jasmani serta meningkatkan semangat dan motivasi siswa dalam mengikuti pembelajaran penjas.

\section{METODE}

Model penelitian dan pengembangan yang digunakan mengadopsi model penelitian dan pengembangan (R\&D) level 3 menurut Borg and Gall yang dikembangkan oleh Sugiyono (2015:407). Desain penelitian ini digunakan untuk mengembangkan produk berupa model latihan kebugaran jasmani berbasis permainan tradisional sebagai aktivitas belajar siswa dalam pembelajaran PJOK. Penelitian ini berfokus pada pengembangan untuk menghasilkan sebuah produk model latihan kebugaran. Dengan mempertimbangkan dampak penyebaran covid-19 maka langkahlangkah penelitian pengembangan ini disederhanakan menjadi 7 langkah, yaitu (1) penelitian produk yang telah ada (studi literatur dan penelitian lapangan), (2) perencanaan dan pengembangan produk, (3) pengujian internal desain (validasi ahli) tahap I, (4) revisi produk I, (5) pengujian internal desain (validasi ahli) tahap II, (6) revisi produk II, (7) finalisasi produk akhir.

Pada tahap uji coba penggunaan produk, peneliti melibatkan 3 orang ahli untuk melakukan validasi terhadap draf produk pengembangan yang telah dibuat (dilengkapi dengan video simulasi penggunaan produk pada siswa SMP). Validasi ahli masingmasing dilakukan sebanyak dua kali. Uji coba internal desain (validasi ahli) pertama dan kedua, bertujuan untuk menilai dan memvalidasi produk awal. Instrumen yang digunakan pada tahap ini adalah angket skala nilai. Subjek uji coba dalam penelitian ini terbatas berjumlah sembilan orang yaitu siswa - siswi kelas VII SMP Citra Bakti Ngada. Keterbatasan subjek karena disesuaikan dengan kondisi di lapangan yakni adanya pembatasan sosial dengan tetap mengikuti protokol covid-19. Subjek dalam penelitian ini akan mengikuti proses pembuatan video simulasi penggunaan produk untuk kemudian dipakai sebagai video tahap pengujian internal desain tahap pertama dan tahap kedua.

Teknik analisis data dalam penelitian pengembangan ini menggunakan dua bentuk teknik analisis data, yaitu analisis data deskriptif kualitatif dan analisis data deskriptif kuantitatif. Teknik analisis data deskriptif kualitatif digunakan pada data-data penelitian yang bersifat teks berupa komentar, catatan, masukan dan saran dari para ahli, sedangkan teknik analisis data deskriptif kuantitatif digunakan pada data-data penelitian yang diperoleh dari hasil validasi ahli pada instrument angket skala nilai. Teknik analisis data digunakan untuk membuat kesimpulan umum dan saran atau masukan dalam kepentingan melakukan revisi produk dan rujukan dalam menarik kesimpulan akhir pengembangan produk serta simpulan akhir penelitian dan pengembangan ini. Analisis data kuantitatif dalam penelitian ini secara rinci dilakukan pada data-data hasil penelitian validasi dengan skala nilai dari para ahli terhadap produk awal pada uji coba internal desain (validasi ahli) tahap pertama dan kedua. Dalam penelitian dan pengembangan ini, digunakan instrumen validasi draf produk awal untuk mengumpulkan data-data penelitian. Instrumen validasi draf produk awal digunakan oleh para ahli untuk melakukan validasi desain produk awal sebelum dikembangkan menjadi produk akhir penelitian. Instrumen yang digunakan untuk validasi produk awal menggunakan instrumen angket skala nilai.

\section{HASIL DAN PEMBAHASAN}

Produk awal model latihan kebugaran jasmani berbasis permainan tradisional yang meliputi, (1) permainan lompat tali, (2) permainan Engklek, dan (3) permainan Balap Karung dinilai oleh para ahli menggunakan instrumen penilaian yang disediakan. Dengan menggunakan skala Likert 1-5, instrumen angket skala nilai terdiri atas 10 butir pertanyaan untuk menguji tingkat kesesuaian produk pengembangan dengan indikator 
yang ditetapkan. Hasil penilaian yang dilakukan oleh ke-tiga ahli (validator) terhadap produk awal dapat diuraikan sebagai berikut.

Tabel 1. Hasil Validasi Ahli Produk Awal (Tahap I)

\begin{tabular}{llllllllllll}
\hline Kode Ahli & \multicolumn{1}{c}{ Butir Soal } \\
\hline \multicolumn{10}{c}{ Skor Penilaian Ahli } \\
\hline A1 & 1 & 2 & 3 & 4 & 5 & 6 & 7 & 8 & 9 & 10 & \\
\hline A2 & 5 & 4 & 3 & 3 & 4 & 3 & 4 & 4 & 3 & 4 & 37 \\
\hline P1 & 5 & 3 & 3 & 3 & 4 & 4 & 3 & 4 & 3 & 4 & 36 \\
\hline
\end{tabular}

\section{Keterangan :}

A1: Ahli 1 (Ahli Akademisi)

A2 : Ahli 2 (Ahli Akademisi)

P1 : Praktisi Guru PJOK

Tabel 2. Perhitungan Normatif Kategorisasi Kesesuaian Produk Awal

\begin{tabular}{ccc}
\hline Formula & Interval & Kategori \\
\hline$X<(\mu-1,0 \sigma)$ & $X<23$ & Kurang sesuai \\
\hline$(\mu-1,0 \sigma) \leq X<(\mu+1,0 \sigma)$ & $23 \leq X<37$ & Cukup sesuai \\
\hline$(\mu+1,0 \sigma) \leq X$ & $37 \leq X$ & Sesuai \\
\hline
\end{tabular}

Berdasarkan data pada tabel 1 dan 2, terlihat penilaian ketiga ahli memiliki ratarata nilai $(36,6)$ berada pada interval $(23 \leq X<37)$, maka dapat dikatakan bahwa model latihan yang dikembangkan Cukup Sesuai sebagai bentuk aktivitas belajar siswa terutama pada materi latihan kebugaran jasmani. Berdasarkan hasil penilaian ahli pada validasi I, selanjutnya produk awal direvisi sebelum dilanjutkan pada tahap validasi yang kedua.

\section{Hasil Pengujian Internal Desain Tahap II}

Produk awal yang telah direvisi pada tahap validasi I, selanjutnya dinilai oleh para ahli. Produk selanjutnya disempurnakan menjadi produk akhir dalam bentuk buku panduan latihan kebugaran jasmani berbasis permainan tradisional. Hasil pengujian internal desain tahap II dapat diuraikan seperti pada tabel 3 berikut ini.

Tabel 3. Data Hasil Pengujian Internal Desain Tahap II

\begin{tabular}{cccccccccccc}
\hline Kode Ahli & \multicolumn{1}{c}{ Butir Soal } & \multicolumn{1}{c}{ Jumlah } \\
\hline \multicolumn{10}{c}{ Hasil Penilaian Ahli } \\
\hline A1 & 1 & 2 & 3 & 4 & 5 & 6 & 7 & 8 & 9 & 10 \\
\hline A2 & 5 & 4 & 4 & 5 & 5 & 4 & 5 & 4 & 4 & 5 & 45 \\
\hline P1 & 5 & 4 & 4 & 4 & 5 & 5 & 5 & 4 & 4 & 4 & 44 \\
\hline
\end{tabular}

Keterangan :

A1 : Ahli 1 ( Ahli Akademisi)

A2 : Ahli 2 (Ahli Akademisi)

P1 : Praktisi ( Guru PJOK) 
ISSN 2356-3397 (Print) | ISSN 2597-4505 (Online)

Tabel 4. Perhitungan Normatif kategorisasi kesesuaian Produk Awal

\begin{tabular}{ccc}
\hline Formula & Interval & Kategori \\
\hline$X<(\mu-1,0 \sigma)$ & $X<23$ & Kurang Sesuai \\
\hline$(\mu-1,0 \sigma) \leq X(\mu+0 \sigma)$ & $23 \leq X<37$ & Cukup Sesuai \\
\hline$(\mu+1,0 \sigma) \leq X$ & $37 \leq X$ & Sesuai \\
\hline
\end{tabular}

(Sumber: Azwar,2012:149)

Berdasarkan data pada tabel 3 dan 4, diketahui hasil penilaian para ahli memiliki rata- rata nilai $(44,3)$ berada pada interval $(37 \leq X)$. Dengan begitu maka model latihan kebugaran jasmani berbasis permainan tradisional yang dikembangkan berada pada kategori SESUAI sebagai bentuk latihan kebugaran jasmani pada materi latihan kebugaran dalam pembelajaran PJOK.

\section{Revisi Produk}

Sesuai hasil penilaian validasi tahap II, selanjutnya produk awal diperbaiki dan disempurnakan sesuai masukan para ahli untuk dibuat menjadi produk akhir dalam bentuk buku panduan latihan kebugaran jasmani.

\section{Produk Akhir Pengembangan}

Hasil penelitian dan pengembangan ini adalah model latihan kebugaran jasmani berbasis permainan tradisional sebagai bentuk aktivitas belajar siswa SMP dalam pembelajaran PJOK. Model latihan ini diberi nama Model Latihan Play4Fit.

\section{Model Latihan Play4Fit}

Model latihan kebugaran jasmani Play4Fit merupakan kombinasi dari tiga jenis permainan tradisional yakni lompat tali, engklek dan balap karung.

1) Permainan lompat tali, dilakukan dengan cara melompat melewati tali yang diatur pada ketinggian tertentu. Teknik melompat diatur dengan cara lompat vertikal hadap depan, lompat vertikal posisi badan menyamping serta gerakan meroda. Latihan ini bertujuan untuk melatih fleksibilitas tubuh, kekuatan otot serta daya tahan otot lengan dan tungkai. Permainan ini dimainkan dengan jumlah minimal 3 siswa dengan rincian, 2 siswa bertugas sebagai pemegang tali (ditentukan dengan cara undian) sedangkan 1 siswa melakukan lompatan. Permainan dilakukan secara bergantian untuk setiap siswa sehingga masing-masing mendapatkan giliran untuk melompat. Permainan lompat tali, dirangkai kedalam 5 bentuk variasi gerakan yakni:

a) Lompat tali setinggi pinggang,

1) Siswa berdiri berhadapan dengan tali dengan jarak minimal 2 meter.

2) Selanjutnya siswa melakukan awalan dengan berlari ke arah tali untuk melakukan lompatan

3) Siswa melakukan gerakan melompat vertikal dengan posisi badan menghadap ke depan.

4) Setelah melompat, gerakan selanjutnya adalah bertumpu pada salah satu kaki.

b) Lompat tali setinggi dada,

1) Siswa berdiri berhadapan dengan tali dengan jarak minimal 2 meter.

2) Selanjutnya siswa melakukan awalan dengan berlari ke arah tali untuk melakukan lompatan

3) Siswa melakukan gerakan melompat vertikal dengan posisi badan menghadap ke samping.

4) Setelah melompat, gerakan selanjutnya adalah bertumpu pada salah satu kaki.

c) Lompat tali setinggi kepala,

1) Siswa berdiri berhadapan dengan tali dengan jarak minimal 2 meter.

2) Selanjutnya siswa melakukan awalan dengan berlari ke arah tali untuk melakukan lompatan. 


\section{ISSN 2356-3397 (Print) | ISSN 2597-4505 (Online)}

3) Siswa melakukan gerakan melompat vertikal dengan posisi badan menghadap ke samping.

4) Setelah melompat, gerakan selanjutnya adalah bertumpu pada salah satu kaki.

d) Lompat tali setinggi 1 jengkal dari kepala,

1) Siswa berdiri berhadapan dengan tali dengan jarak minimal 2 meter.

2) Selanjutnya siswa melakukan awalan dengan berlari ke arah tali untuk melakukan lompatan.

3) Siswa melakukan gerakan melompat vertikal dengan posisi badan menghadap ke samping.

4) Setelah melompat, gerakan selanjutnya adalah bertumpu pada salah satu kaki.

e) Lompat tali setinggi 2 jengkal dari kepala.

1) Siswa berdiri berhadapan dengan tali dengan jarak minimal 2 meter.

2) Selanjutnya siswa melakukan awalan dengan berlari ke arah tali untuk melakukan gerakan meroda untuk melewati tali.

3) Sesaat akan mendekati tali, siswa melakukan gerakan meroda dengan cara meletakkan kedua telapak tangan pada lantai (posisi badan menyamping dengan tali), bersamaan dengan itu kedua kaki didorong tegak lurus ke atas secara bersamaan untuk melewati tali.

4) Selanjutnya mendorong tubuh untuk berdiri sehingga kedua kaki secara bersamaan kembali bertumpu pada lantai.

2) Permainan engklek, dimainkan dengan cara melakukan gerakan mendorong bola menggunakan kaki untuk melewati area permainan berbentuk kotak. Bola yang digunakan dapat berupa bola pingpong, bola plastik berukuran kecil ataupun bola kasti. Lapangan permainan engklek berbentuk kotak yang berjumlah 6 kotak dengan ukuran masing-masing kotak memiliki panjang $50 \mathrm{~cm}$ dan lebar $50 \mathrm{~cm}$ (perhatikan gambar 1). Lapangan permainan dapat dibuat dengan menggunakan garis pada lantai, atau dapat juga memodifikasi menggunakan tali bekas untuk membentuk kotak. Permainan engklek dapat dilakukan oleh sekurang-kurangnya 2 orang siswa. Permainan dilakukan dengan cara mendorong bola menggunakan salah satu kaki dari 1 kotak ke kotak lainnya secara berurutan. Jika pada saat mendorong bola, bola melewati garis batas melebihi 1 kotak atau keluar dari lapangan permainan maka permainan dihentikan dan diganti dengan siswa lainnya. Permainan ini bertujuan untuk melatih kekuatan otot tungkai dan keseimbangan dinamis.

\begin{tabular}{c|c|c|c|}
\cline { 2 - 3 } start & 1 & 2 & 3 \\
\cline { 2 - 4 } finish & 6 & 5 & 4 \\
\cline { 2 - 4 } & &
\end{tabular}

\section{Gambar 1. Lapangan Permainan Engklek}

\section{Cara bermain engklek}

a) Bola diletakkan pada kotak 1 . Siswa berdiri dengan posisi salah satu kaki berada tepat dibelakang bola sedangkan kaki lainnya ditekuk.

b) Pada aba-aba mulai, siswa mendorong bola ke kotak ke 2 hingga ke kotak 6 secara berurutan menggunakan ujung kaki.

c) Gerakan berakhir ketika telah melewati kotak 6 .

3) Permainan Balap Karung, merupakan permainan yang dimainkan dengan cara berdiri di dalam sebuah karung dengan posisi kedua tangan memegang bagian atas karung dan ketika ada aba-aba berupa bunyi peluit, peserta langsung berlari secepat mungkin dari garis start dan melewati garis finis. Tujuan permainan ini adalah untuk melatih daya tahan jantung paru, koordinasi gerak, keseimbangan serta kekuatan. 


\section{Volume 8, Nomor 1, April 2021 \\ ISSN 2356-3397 (Print) | ISSN 2597-4505 (Online)}

Pada model latihan Play4Fit, permainan balap karung dibuat menjadi 3 bentuk variasi yakni sebagai berikut.

a) Lari karung biasa

1) Siswa berdiri di dalam karung dengan posisi kedua tangan memegang bagian atas karung.

2) Ketika bunyi peluit, siswa berlari secepat mungkin untuk melewati garis finis.

b) Lari karung dengan karung dilubangi (bagian sudut karung diberi lubang untuk ibu jari kaki).

1) Siswa berdiri di dalam karung dengan posisi kedua tangan memegang bagian atas karung.

2) Posisi ibu jari kaki berada diluar karung

3) Saat ada bunyi peluit, siswa berlari secepat mungkin untuk melewati garis finis

c) Lari karung 2in1

1) Permainan ini dilakukan dengan cara, 2 orang siswa meletakkan masing-masing salah satu kaki di dalam satu karung yang sama.

2) Saat bunyi peluit, siswa memegang bagian atas karung dan berlari secepat mungkin melewati garis finis.

\section{Tujuan \& Manfaat Model Latihan Play4Fit}

Kombinasi ketiga jenis permainan dalam model latihan yang dikembangkan ini bertujuan untuk:

1) Sebagai alternatif pilihan bagi guru PJOK mengenai model latihan kebugaran jasmani yang menarik dan menyenangkan bagi siswa SMP dalam pembelajaran penjas.

2) Membantu siswa agar dapat melakukan latihan kebugaran jasmani secara optimal.

3) Merangsang siswa bergerak aktif selama pembelajaran penjas terkhusus materi latihan kebugaran jasmani.

\section{Tahap Pelaksanaan Model Permainan}

Pada kegiatan inti pembelajaran Penjas, model latihan Play4Fit ini diatur dalam tiga sesi dengan 3 pos permainan. Siswa dibagi kedalam tiga kelompok secara merata. Masing-masing kelompok akan bermain pada tiap pos permainan secara bergantian sesuai dengan durasi waktu yang diberikan. Berikut rincian tahap pelaksanaan permainan Play4Fit.

Tabel 6. Tahap pelaksanaan model latihan Play4Fit

\begin{tabular}{ccccc}
\hline Sesi & $\begin{array}{c}\text { Pos A } \\
\text { (Lompat Tali) }\end{array}$ & $\begin{array}{c}\text { Pos B } \\
\text { (Engklek) }\end{array}$ & $\begin{array}{c}\text { Pos C } \\
\text { (Balap Karung) }\end{array}$ & Waktu \\
\hline I & Kelompok 1 & Kelompok 2 & Kelompok 3 & 30 menit \\
\hline II & Kelompok 3 & Kelompok 1 & Kelompok 2 & 30 menit \\
\hline III & Kelompok 2 & Kelompok 3 & Kelompok 1 & 30 menit \\
\hline
\end{tabular}

Model latihan ini berfokus pada desain rangkaian aktivitas gerak permainan yang memenuhi kategori 'SESUAl' untuk digunakan dalam materi latihan kebugaran jasmani siswa SMP dengan spesifikasi khusus meliputi: bentuk latihan sederhana, rangkaian gerak fisik mudah dan aman dilakukan, biaya dan fasilitas murah dan mudah diperoleh, serta variasi permainan yang menarik. Berdasarkan data hasil penilaian para ahli, disimpulkan bahwa (1) model latihan play4fit memenuhi kategori sesuai karena bentuk latihan sesuai dengan indikator pada materi latihan kebugaran jasmani sebagai aktivitas belajar siswa dan sesuai digunakan pada jenjang SMP. Latihan kebugaran jasmani pada prinsipnya meliputi beberapa komponen biomotor meliputi daya tahan jantung paru, kekuatan dan daya tahan otot, fleksibilitas serta komposisi tubuh. (2) rancangan intensitas dan durasi latihan cocok digunakan sebagai aktivitas belajar siswa dalam 
pembelajaran PJOK. Latihan kebugaran jasmani akan memberikan manfaat yang maksimal jika dilakukan dengan intensitas dan durasi yang tepat. Model latihan play4fit yang didesain dengan intensitas latihan berada pada tingkat sedang dengan durasi berkisar antara 90 menit dalam pembelajaran PJOK akan berpengaruh baik bagi kebugaran siswa (3) peralatan yang digunakan mudah didapat. Sarana prasarana yang diperlukan dalam pelaksanaan model latihan play4fit seperti karet gelang, bola plastik serta karung bekas sangat mudah diperoleh dengan biaya yang relatif murah, (4) model latihan play4fit memiliki unsur- unsur permainan tradisional yang dominan. Sebagian besar rangkaian aktivitas gerak yang didesain dalam model latihan ini diadopsi dari tiga jenis permainan tradisional yang secara keseluruhan memiliki karakteristik permainan yang umumnya sederhana, menarik serta kompetitif (5) desain aktivitas gerak yang dibuat memungkinkan siswa mudah untuk melakukanya karena diadopsi dari bentuk permainan tradisional yang sering dimainkan dikalangan siswa usia SMP, (6) model latihan dengan pendekatan pembagian pos-pos permainan memungkinkan siswa bergerak aktif, total serta kompetitif, (7) variasi bentuk gerakan maupun jenis permainan memungkinkan siswa tidak mudah jenuh, (8) model latihan play4fit jika dilakukan dengan benar akan memungkinkan adanya respon dan adaptasi latihan yang baik untuk menunjang tingkat kebugaran jasmani siswa SMP. Respon yang dimaksud adalah reaksi fisik siswa setelah melakukan setiap rangkaian gerak fisik dalam permainan. Indikator sederhana dari respon latihan adalah kondisi irama pernapasan yang terlihat lebih cepat, tubuh berkeringat, serta peningkatan denyut nadi merupakan bentuk nyata dari respon latihan secara fisiologis. Sedangkan adaptasi latihan merupakan kondisi dimana latihan yang dilakukan mengakibatkan adanya perubahan keterampilan gerak pada siswa. Perubahan kemampuan gerak yang dimaksud meliputi beberapa aspek seperti perubahan kelincahan siswa dalam bergerak, fleksibilitas tubuh yang semakin bertambah, daya tahan jantung paru yang lebih baik serta aspek kekuatan dan daya tahan otot yang lebih baik terhadap beban aktivitas gerak yang dilakukan.

\section{SIMPULAN DAN SARAN Simpulan}

Penelitian ini menghasilkan produk akhir berupa buku panduan model latihan kebugaran jasmani Play4Fit berbasis permainan tradisional sebagai aktivitas belajar siswa SMP dalam pembelajaran PJOK. Model latihan Play4Fit merupakan kombinasi dari permainan lompat tali, engklek, dan balap karung. Total durasi permainan \pm 90 menit. Produk akhir pengembangan disusun dalam bentuk buku panduan latihan yang diberi judul: "Play4Fit. Panduan latihan kebugaran jasmani berbasis permainan tradisional sebagai aktivitas belajar siswa SMP dalam pembelajaran PJOK".

\section{Saran}

Berdasarkan hasil pengembangan yang dilakukan, berikut dapat disarankan beberapa hal: 1) bagi mahasiswa PJKR maupun guru PJOK dapat memanfaatkan produk hasil pengembangan ini sebagai salah satu alternatif model latihan kebugaran jasmani dalam pembelajaran PJOK bagi siswa SMP, 2)produk pengembangan ini diperuntukkan khusus sebagai salah satu alternatif aktivitas belajar siswa SMP dalam pembelajaran PJOK pada materi latihan kebugaran jasmani. 2) hasil pengembangan ini perlu diuji efektivitas penggunaannya pada populasi yang lebih luas. 
DAFTAR PUSTAKA

Ardiwinata, Hartini. (2006). Pemanfaatan Permainan tradisional. Jakarta: Bumi Siliwangi.

Bile, R. L. \& Suharharjana, S. (2019). Efektivitas penggunaan model latihan kebugaran "Bbc Exercise" untuk pemeliharaan kebugaran jasmani mahasiswa. SPORTIVE: Journal of Physical Education, Sport and Recreation, 3 (1), 30-37, DOI: https://doi.org/10.26858/sportive.v3i1.16857

Bile, R. L. (2019). Pengembangan model latihan olahraga kesehatan berbasis breathing exercise, bodyweight training dan core stability exercise untuk pemeliharaan kebugaran jasmani mahasiswa. Thesis S2 (versi cetak) IImu Keolahragaan Program Pascasarjana UNY.

Giriwijoyo, S. (2012). IImu faal Olahraga. Bandung: ITB.

Irianto, D. P. (2017). Panduan gizi lengkap keluarga dan olahragawan. Yogyakarta: Andi Offset.

Lutan, Rusli, dkk. (2001). Pendidikan kebugaran jasmani: orientasi pembinaan sepanjang hayat. Jakarta: Dirjen Pendidikan Dasar Dan Menengah Dirjen OR.

Monyeki, M. A., Neetens, R., Moss, S. J., \& Twisk, J. (2012). The relationship between body composition and physical fitness in 14 years old adolescents residing within the Tlokwe local municipality, South Africa: The PAHL study. BMC Public Health 2012, 12: 374. http://www.biomedcentral.com/1471-2458/12/374.

Nugroho, A.S. 2015. Perbedaan tingkat kebugaran jasmani siswa kelas VI, VIII, IX SMP NEGERI I Kota Mungkid Kabupaten Magelang. Skripsi. Yogyakarta: Fakultas IImu keolahragaan Program Studi Pendidikan Jasmani Kesehatan dan Rekreasi Universitas Negeri Yogyakarta.

Powell, M. A. (2011). Physical fitness: training, effects, and maintaining. Nova Science Publishers, Inc. New York.

Suharjana. (2008). Pendidikan Kebugaran Jasmani. Pedoman Kuliah. Yogyakarta FIK UNY.

Sugiyono. (2015). Metode Penelitian Kuantitatif kualitatif dan R\&D.Bandung:Alfabeta.

Suroto. (2004). Buku pegangan kuliah pengertian senam, manfaat senam dan urutan gerakan. Semarang: Unit Pelaksana Teknis Mata Kuliah Umum Olahraga UNDIP.

Tapo, Y.B.O. \& Bile, R.L. (2020). Evektivitas pengunaan model latihan olahraga pernapasan monacors untuk pemeliharaan kesehatan fungsi paru bagi mahasiswa dalam menghadapi pandemi covid-19. Ejurnal IMEDTECH, 4(2), 5465. DOI: http://dx.doi.org/10.38048/imedtech.v4i2.226

Tapo, Y.B.O. (2020). Evaluasi status kebugaran jasmani dan tingkat penguasaan keterampilan olahraga sepakbola dan bola voli mahasiswa PJKR semester V STKIP Citra Bakti Ngada berdasarkan aktivitas perkuliahan praktek dan pembinaan kegiatan UKM. Ejurnal IMEDTECH, 4(1), 37-54, DOI: http://dx.doi.org/10.38048/imedtech.v4i1.223 